\title{
John Locke: The Construction of Knowledge in the Perspective of Philosophy
}

\author{
Juhansar ${ }^{1}$ \\ ${ }^{1}$ Program Studi Informatika, Universitas Teknologi Yogyakarta, Indonesia \\ E-mail: juhansar@uty.ac.id ${ }^{1}$
}

\begin{abstract}
Epistemology is one of the trichotomies of philosophy that raises two main isms, rationalism and empiricism, in obtaining knowledge. Rationalism was initiated by Rene Descartes (1596-1650), and empiricism was initiated by John Lock (1632-1704). As an empiricist, Locke offers the tabula rasa theory to support his arguments on the philosophy of knowledge. This study aims to describe radically and comprehensively Locke's concept of knowledge from the perspective of philosophy. This aim is achieved by describing the background and principal works of John Lock on the philosophy of epistemology, including the main ideas, views, and reasoning of his empiricism through tabula rasa theory. The method used in this research is descriptive qualitative in the field of philosophy. Data were collected through a literature study, then analyzed hermeneutically with two methodical elements, verstehen and interpretation. This study shows that first knowledge is principally obtained from sensory experience in which the mind is only passive. Second, the sensory experience is obtained objectively (primary quality) and subjectively (secondary quality). Third, external sensation and internal sensation obtained from sensory experience are built into simple ideas to complex ideas.
\end{abstract}

Keywords: philosophy; epistemology; empiricism; tabula rasa; John Locke.

\section{Introduction}

Knowledge in philosophy is called epistemology. Epistemology is one of the trichotomies of philosophy; ontology, axiology, and epistemology itself. Hardono Hadi (2001), in his foreword to the book, "Epistemology of the Philosophy of Knowledge," which is adapted from Kenneth T. Gallagher's book, "The Philosophy of Knowledge," states that "...Plato can be said as the originator of epistemology or philosophy of knowledge because he was the first one processing basic problems, such as: What is knowledge? Where is knowledge generally found, and to what extent do we usually think of knowledge as real knowledge? Do the senses give knowledge? Can the mind produce knowledge? What is the relationship between right knowledge and belief?". The problems mentioned above, among others, according to Hadi (2001), deal with epistemology. Although it seems simple, the material grows and gets more complicated as the opinions grow. Thus, the problems faced by epistemology are not getting simpler but more complex. It causes difficulties for novice learners of epistemology in starting an effort to understand these epistemological problems (Hadi, 2001).

Feriere, in 1864, from the Institute of Metaphysics, was the first person to use the term epistemology to distinguish between two branches of philosophy, namely epistemology and ontology (Mintaredja, 2003). Epistemology comes from the Greek word, namely episteme, which means knowledge, and logos which means knowledge or information. Thus, epistemology can be said as knowledge about knowledge, and it is sometimes referred to as the "theory of knowledge" (Bagus, 2000). Philosophically, epistemology examines knowledge's nature, scope, presuppositions, and accountability (Hadi, 2007). Knowledge is a treasure trove of mental wealth that directly or indirectly contributes to enriching our lives. Knowledge can also be said to be the answer to various questions that arise in life. A question is expected to get the correct answer (Suriasumantri, 1993: 105). If it is expected to get a correct answer from a question, then the question is then, how to give the correct answer? How do humans acquire knowledge or correct answer? What are the adequate means of attaining proper knowledge? In answering these epistemological questions, Munir (2008) suggests that at least two schools can give different or even contradictory answers to these questions. The two schools in question are rationalism and empiricism.

The rationalists, pioneered by René Descartes (Latin: Renatus Cartesius) (1596-1650), stated that knowledge is obtained through mind or reason (Nasution, 1989). In other words, rationalism believes that some ideas or concepts are independent of experience and that truth 
can be known only by reason (Hunnex, 2004). The father of modern philosophy, Descartes, consequently doubted the knowledge obtained by the senses or experience. For him, it does not mean that rationalism denies the value of experience, but that experience is at least seen as a stimulus to the mind. On the other hand, empiricists, pioneered by Francis Bacon (1561-1626) (Verhaak, 1993), and Thomas Hobbes (1588-1679), and then developed by John Locke (16321704), assumes that humans can gain knowledge through experience. Knowledge is obtained through the mediation of the five senses (Kattsoff, 2004). However, it does not mean that rationalism is rejected. In other words, rationalism is used in terms of empiricism (Hadiwijono, 1980).

Along with the debate where rationalism remains adamant, certainties are a priori, or knowledge comes from the mind where experience is only passive. On the other hand, empiricists also believe that science is not a priori, but aposteriori or knowledge comes from "sensory experience" or empeiria, in which reason is passive. One of the two schools mentioned above will be discussed in-depth in this article, namely empiricism. However, in this article, the researcher only examines empiricism from the last figure mentioned in the epistemological school, namely John Locke. The father of British empiricism was chosen because empiricist thought became more popular in his time. Thus, this study aims to describe radically and comprehensively the concept of John Locke's thought from the perspective of epistemological philosophy. To achieve this goal, the researcher first expresses Locke's background or life history, including his most influential masterpieces that, according to the researcher, are relevant to be described. Furthermore, the researcher describes Locke main thoughts, views, and reasoning of the empiricism in detail, especially in terms of epistemological philosophy, and ends with comments and criticisms of the researcher.

\section{Method}

This research is descriptive qualitative research in philosophy in which data are collected through a literature study. Literature studies, online and offline, are used to obtain primary and secondary data about John Lock's background or life history, including his works and main ideas, views, and reasoning related to the philosophy of epistemology. Primary data are data about the philosophy of epistemology obtained directly from the works of John Lock, while secondary data are data obtained from the works of other scholars who discuss John Locke and his philosophical thoughts on epistemology.

The collected data, primary and secondary, are then read, understood, and recorded in the form of quotations, paraphrases, synoptic or summary, and precis. The researcher determines the categories of data that have been collected by displaying and classifying. Data classification aims to determine the type of data, primary data or supporting (secondary) data. Data classification is also intended to determine data related to the points discussed in this study. Finally, the researcher analyzed the data using the philosophical hermeneutic method. This method is used by considering coherence, comprehensiveness, thoroughness, contextual, suggestive, and potential, which relies on two methodical elements: verstehen and interpretation. Verstehen (understanding), which is also interpreting (interpreting), is called hermeneutics (van Peursen, 1985: 54). Verstehen is used to capture the meaning of a text related to the discussion studied in this paper; words as if penetrated to enter the meaning of the implied text initially. Meanwhile, interpreting is carried out as a follow-up to the previous methodical element. This element is applied to capture and criticize the concepts of John Locke's philosophical thought.

\section{Results and Discussion}

\section{a. John Locke and His Works}

The father of British empiricism (1632-1704), John Locke, was born on August 28, 1632, in Wrington, England. Locke was born into the Somerset family, descended from a good family who supported the parliamentary system during the civil war (Hadi, 2008). His family is from the middle class. His father owned several houses and land around Pensford, a small town in the southern part of Bristol. Apart from working as a landowner, Locke's father also worked as a lawyer and performed administrative duties in the local government. In 1647, Locke studied at the Westminster School, which was the most famous school in England. Education there centred on the study of ancient languages, namely Latin, Greek, and also Hebrew. After that, in 1652, Locke received a scholarship to study at the Christ Church School, Oxford, and lived there since May 1652 (Schmadt, 2005).

Locke began to enjoy the medical (medicine) and natural sciences, as written in some of Locke's notes written in the late 1650s. He made many notes on matters related to health and 
medicine. Through his interest in medicine, Locke began to be interested in natural philosophy as early as 1658 . In early 1660 , he met Robert Boyle, who would influence him much later. From 1660 Locke increased his interest by reading the newly emerging mechanical philosophy, beginning with Boyle's work. In addition, Locke also began to diligently read the works of Descartes (Solomon and Higgins, 2003). After Descartes' works, he became interested in philosophy and then opposed the views of Descartes, the originator of rationalism. As evidence of his opposition, at the age of 58 years or in 1690, he published his famous work entitled "Essay Concerning Human Understanding" (Hadi, 2008).

In June 1700, Locke retired from his government job. He lived the rest of his life for four years in peace and did not visit London very often. However, Locke was still working on another writing entitled "Paraphrase and Notes on the Epistles of St Paul" (Locke, 1823). This work reveals the depth of the religious character of Locke's thought. Increasingly, Locke's health deteriorated in the last years of his life, and he developed asthma. His last visit to London in January 1698 at the summons of King William III made his health worse, and the final months of 1704 were the last moments of his life. He died in Oates, England, on October 28, 1704, and was buried in High Laver (Hamersma, 1983).

John Locke has many works, but in this study, the researcher will only reveal three of them that are considered most important and relevant to the discussion of this research, including: "Essay Concerning Human Understanding" (1690), "Letter on Tolerations" (1689-1690) -1692), and "Two Treatizes on Government" (1690) (Hamersma, 1983). The first book mentioned in the work of Locke made his name soar. In this work, Lock questions the origin, nature, and limitations of human knowledge. Locke's ideas, in turn, influenced philosophers such as George Berkeley, David Hume, and Immanuel Kant. Although the essay is Locke's most original work and is one of the most famous classical philosophical writings, it is not as influential as other writings dealing with political issues (Russell, 2004).

His subsequent work is "Letters on Toleration." In this work, Locke emphasizes that the state should not practice worship according to their respective religious beliefs. Locke was not the first Englishman to propose religious tolerance of all Protestant sects. Nevertheless, his strong argument favours the need for tolerance to support the population for their views. Moreover, Locke developed his principle of tolerance for non-Christians: "... both adherents of primitive beliefs, or Islam or Judaism, should not be deprived of their civil rights in the state solely on the grounds of religion." By today's standards, he can be very tolerant, but it is reasonable to view him from the relationship with the ideas of his time. The fact notes that he aims to create religious tolerance by convincing his readers more than the exceptions he makes. Now, thanks to Locke's writings, religious tolerance has expanded even to groups that were previously excluded (Russell, 2004).

As described in this research, Locke's last significant work is "Two Treatizes on Government," which is a view and analysis of the stages of community development. This work influenced political minds throughout the English-speaking world. Locke firmly believed that every human being has natural rights, and this is not just about life but also personal freedom and property rights. The government's main task is to protect citizens' population and property rights (Russell, 2004). Based on the explanation above, it can be concluded that the first work, according to the researcher, is the most relevant work related to the philosophy of epistemology, while the second is about religious tolerance and the last is a work about the state or government.

\section{b. John Locke's Construction of Knowledge 1) Empiricism and Tabula Rasa Theory}

The word empiricism comes from the Greek word empeirikos or empeiria, which means experience. Empiricism is a philosophical doctrine that emphasizes experience in acquiring knowledge by understating the role of reason. According to this school, humans acquire knowledge through experience and then return to the Greek word, the experience in question is a sensory experience. A man knows ice is cold because he touches it; sugar is sweet because he tastes it (Tafsir, 2008). An empiricist usually argues that we can gain knowledge through experience. The salient nature of this answer can be seen when we pay attention to questions such as, "How do people know ice is frozen?", our answers would be, "because I see it that way," or "because a scientist sees it that way." In this way, two kinds of elements can be distinguished: the knowing element and the known element. People who know are subjects who gain knowledge and are known by words that show someone or an ability.

The next element that we can distinguish in answer to the question "How do people know that the ice is frozen?" is our state of seeing, hearing, or other sensory experience. "How do we 
know fire is hot?" by touching something or getting the experience we call heat. "How do we know what heat is?", the answer: we know it with the senses of touch. Next, the question: "How do you know or acquire knowledge?" answered by demonstrating appropriate sensory experiences. "Knowledge is obtained through the mediation of the senses," says empiricists (Praja, 2003). Whitehead sees that for Locke, ideas about external objects are formed due to stimulation of the mind by external objects through sensation (Hadi, 2000).

Locke put forward the theory of tabula rasa, which lexically means "table of candles." The point is that man is initially empty of knowledge, then his knowledge fills the empty soul, then he knows. At first, since capture is simple, it becomes complicated, then meaningful and meaningful knowledge is composed over time. It shows that no matter how complex (complicated) human knowledge is, it can always be reached through sensory experience. Something that cannot be observed with the senses is not proper knowledge. So, sense experience is the source of proper knowledge. Therefore, the research method that is the foundation of this flow is the experimental method (Tafsir, 2008).

There are two main characteristics of empiricism: the theory of meaning and the theory of knowledge or commonly called the theory of meaning. The theory of meaning in empiricism is usually expressed as a theory about the origin of knowledge, namely ideas or concepts. In the Middle Ages, this theory was summarized in the formula Nihil est in intellectu quod non-prius fuerit in sensu (there is nothing in our mind but preceded by experience). This statement is Locke's thesis in his book, An Essay Concerning Human Understanding, which he issued when he opposed the teaching of innate ideas to rationalists. The soul (mind), when a person is born, is empty, like a white paper or tabula rasa, which has not been written on it, and every idea it acquires must come through experience; What is meant by experience here is a sensory experience. In other words, that knowledge comes from the observations we make of our soul (mind) with a tool that Locke calls inner sense (Tafsir, 2008).

In the twentieth century, empiricists tended to use their theory of meaning to determine whether a concept was applied correctly or not, not to the origin of knowledge. One example of this practical use of empiricism is in Charles Sanders Peirce's sentence, "Determine what influence the concept has on practice that can be understood than the concept of that influence, that is the concept of the object." The empiricist philosophy of the theory of meaning is very close to the flow of logical positivism (logical positivism) and the philosophy of Ludwig Wittgenstein. However, the theory of meaning and empiricism must always be understood through the interpretation of experience. Therefore, for the empiricist, the soul can be understood as a wave of conscious experience, matter as a pattern (pattern) of perceivable quantities, and causality as a sequence of similar events.

The second theory is the theory of knowledge. According to rationalists, there are some general truths, such as "every event must have a cause," the basics of mathematics, and some basic ethical principles, and these truths are true by themselves known as a priori truths obtained through rational intuition. Empiricism rejects that opinion. There is no rational intuition. All the truths, as mentioned earlier, are obtained through observation, so they are aposteriori truths (Tafsir, 2008). In his work, "Essay Concerning Human Understanding" (1690), Locke was written that all knowledge comes from experience. It means that there is no idea or concept about something behind experience; there is no derived idea as taught by Plato. In other words, Locke rejected the innate idea, including what Descartes taught, Clear and distinctive idea. Good ideas from Spinoza, the truth of reason from Leibniz, he all rejected.

For Locke, innate knowledge does not exist. This view is based on several arguments, including; a) the entry point for human knowledge is knowing that the innate does not exist. It is relatively common for people to think that innate exists. It is as if it was placed on the human soul, and the soul brought it into this world. Reality is sufficient to explain to man how knowledge comes, that is, through natural forces without the aid of innate impressions, and man arrives at belief without a genuine understanding; $b$ ) general agreement is a strong argument. There is nothing that the general public can agree about the innate idea as an inherent power. This argument is withdrawn from the general agreement. How can we say that the innate idea exists when the public does not acknowledge it; c) general agreement proves the absence of an innate idea; $d$ ) innate ideas are impossible to admit and at the same time not to be acknowledged. The evidence says an innate idea is used as an excuse to say it does not exist; e) neither imprinted nor placed on the soul because, in idiot children, innate ideas do not exist. Typical children and idiots both think. These arguments directly deny an innate idea; even if it exists, it cannot be proven. Indeed, Locke argues, "let us suppose that the soul is like a blank paper (tabula rasa), containing nothing, nor any ideas in it; how does it contain anything?" To answer this question, Locke says "from 
experience"; all knowledge is obtained, and from it, all knowledge originates. It is only this premise that Locke maintains and uses. He also attacks the innate idea through induction (Tafsir, 2008).

The tabula rasa theory, in principle, leaves no room for the notion that a person is born with the blood of an artist, the blood of a businessman, the blood of a worker, or other blood, and illustrates that humans are destined to undergo certain professions from birth. This theory shows that the children of an entrepreneur tend to become entrepreneurs, and the children of a labourer tend to become labourers. The child of an artist tends to become an artist due to education in the environment experienced every day. A businessman child who interacts with his parents, who are also entrepreneurs every day, hears what his parents say about his business every day, will learn to understand the concepts that his parents understand about wealth, how to get it, and have behaviour similar to his parents. So, if an entrepreneur's baby is swapped for an artist's baby, it is very likely that an entrepreneur's baby raised by an artist will become an artist, and the artist's baby raised by an entrepreneur will become an entrepreneur. This theory motivates us that we can become whatever we choose if we want to learn. The environment does affect the type of knowledge we acquire, but when we realize that we can choose, we also can learn to realize our choices (Yuana, 2010).

\section{2) Primary Quality and Secondary Quality}

The discussion of primary and secondary qualities reminds researchers of the saying that "every stick that is put in water bends" and "every stick that is put into water looks bent." Is the object perceived by the senses the same as that which is in the object? Is what the senses perceive objective? What about the impressions we experience? Our eyes see that the stick that we partially dip into the water bends. If we touch the stick, it is clear that it remains straight. According to Locke, when we look at an object, we perceive some qualities of that object. He then classified these qualities into two categories. The first is the primary quality, namely the qualities possessed by the object, including its size and weight. For Locke, this primary quality will remain, whoever measures it. The second is secondary quality, namely the quality of an object that depends on how the researcher sees the object to continue to change according to existing conditions. For example, smell, colour, and sound are very dependent on the sensitivity of our senses. If the lighting quality changes, the colours will likely change too. Thus, science focuses more on primary quality because primary quality is more specific and objective than secondary quality (Wattimena, 2010).

Another way to categorize primary and secondary quality is to mention objective quality in the primary and subjective quality in the secondary quality category. The objective quality is the quality attached to the object, while the secondary quality is the quality of our mind's perception. There is a conundrum (complex) problem that arises when using Locke's concept of knowledge to answer the question, "Does a tree falling in the middle of a forest without anyone to hear its voice make a sound? Consequently, Locke's theory would explain that the collapse of a tree makes no sound, only vibrates the air and objects around it. Sound is a subjective quality, and a vibrating object is an objective (Yuana, 2010). Thus, Locke's view leads to scientific essentialism, which suggests that without the mind perceiving a subjective quality, that quality does not exist.

\section{3) External Sensation and Inner Sensation}

Locke states that there are two kinds of human experience: external experience (sense or external sensation) and inner experience (internal sense or reflection). External experience captures sensory activity, namely all material activities related to the five human senses. Then the inner experience occurs when humans are aware of their activities by 'remembering,' 'wanting,' 'believing,' and so on. These two forms of human experience will shape knowledge through the following process. The next process is referred to as "simple ideas" and "complex ideas."

The combination of two forms of human experience, external experience and inner experience, is obtained what Locke calls "simple ideas" that function as empirical data and "complex ideas." Simple ideas have four types of simple views, including a) views that are only received by one human sense, such as colours are received by the eyes, and the ears receive sounds; b) views perceived by some of the senses, for example, space and motion; c) views produced by the reflection of human consciousness, for example, memory; d) the view that accompanies the moments of the process of acceptance and reflection, for example, a sense of interest, a sense of wonder, and time. 
In simple views, the human mind or ratio is passive or has not yet functioned. After these simple views are available, then the ratio or mind works to form "complex ideas" (complex ideas). The ratio works to form complex views by comparing, abstracting, and connecting these simple views. Three types of complex views are formed during the process, including a) substance or something that stands alone, for example, knowledge about humans or plants; b) Modi (way of being things) or complex views whose existence depends on the substance, for example, the day is the mode of day; c) causality, for example, the view of causality in the statement: "water boils because it is heated to a temperature of $100^{\circ}$ Celsius."

At the end of this discussion, the researcher sees that John Locke (1632-1704) seems to put aside the concepts of thinking about knowledge promoted by Rene Descartes, who thinks that "knowledge comes from reason or reason." For Locke, science is better. Knowledge does not come from reason or reason but a sensory experience. However, is what the senses perceive the same as what is inside the object itself? Is what the senses perceive objective? What about the impression deceptions we experience regarding primary and secondary qualities, as in the examples described above? Our eyes see that the stick that we partially dip into the water bends. If the stick, if we touch it, clearly remains straight? Are the testimonies of our senses misleading? Even more exciting, the taste of sugar on our tongue tastes sweet in healthy conditions but becomes bitter when we are sick, especially if exposed to Covid-19, then the sweet taste of sugar will not taste sweet at all. So where is the sweetness, in the sugar or on our tongues? Reality is in the subject (which has the senses) or in the object (sensed)? In other words, is our knowledge subjective (depending on the subject) or objective (depending on the object)?

\section{Conclusion}

John Locke: Father of British Empiricism (1632-1704), in his thesis, stated that "experience, in that all knowledge is founded." The quote can give a picture of him as an empiricist where the main emphasis is on "aposteriori." For Locke, philosophy is not the only discipline to be pursued but also natural and medical sciences and medicine. In addition, his works are not only limited to philosophy but also religious and state concepts, as reflected in his second and third famous works. However, among his works, the first one closely related to epistemology, "Essay Concerning Human Understanding," is the work that made him famous. Concerning the philosophy of epistemology, the researcher can conclude that at least some of Locke's main ideas or concepts about knowledge are the primary concern in this study. First, the main ideas in question are empiricism, commonly referred to as aposteriori and tabula rasa theory. Science comes from sensory experience, where the brain is like a piece of white paper that will only be filled through sensory experience (ratio or reason is only passive). Second, the dichotomy between primary and secondary quality becomes a problem in determining the "legitimacy" of the knowledge obtained. Third, outward experiences and inner experiences or external sensations and internal sensations give birth to simple and complex ideas.

\section{References}

Bagus, Lorens. 2000. Dictionary of Philosophy (Kamus Filsafat). Jakarta: PT Gramedia Pustaka Utama Jakarta.

Hadi, Protasius Hardono. 2000. Human Identity: Whitehead Orgasm Philosophy. (Jati Diri Manusia: Berdasarkan Filsafat Orgasme Whitehead) Yogyakarta: Kanisius.

Hadi, Protasius Hardono. 2001. Philosophy of Knowledge Epistemology (Epistemologi Filsafat Pengetahuan). Yogyakarta: Kanisius.

Hadi, Protasius Hardono. 2007. Foreword in Aholiab Watloly "Knowledge Responsibilities: Considering Epistemology Culturally (Tanggung Jawab Pengetahuan: Mempertimbangkan Epistemologi secara Kultural)" Yogyakarta: Kanisius in Collaboration with Yayasan Adikarya Ikapi and the Ford Foundation.

Hadi, Protasius Hardono. 2008. Filsafat untuk Pemula, translated from Richard Osborne's Book, "Philosophy for Beginners". Yogyakarta: Kanisius.

Hadiwijono,Harun. 1980. The Essence of Western Philosophy History 2 (Sari Sejarah Filsafat Barat 2). Yogyakarta: Kanisius.

Hamersma, Harry. 1983. Figures of Modern Western Philosophy (Tokoh-tokoh Filsafat Barat Modern). Jakarta: Lembaga Penelitian dan Pengembangan Filsafat STF Driyarkara in Collaboration with PT Gramedia Jakarta. 
Hunnex, Milton D. 2004. Chronological and Thematic Charts of Philosophies and Philosophers, translated by Zubair dan Ali Noer Zamana, "Philosophy: Chronological and Thematic Approach (Filsafat: Pendekatan Kronologis dan Tematis)". Jakarta: Teraju PT Mizan.

Kattsoff, Louis. 2004. Element of Philosophy, translated by Soejono Soemargono, "Pengantar Filsafat". Yogyakarta: Tiara Wacana Yogya.

Locke, John. 1823. The Work of John Locke, Bequeathed by Mrs Anna Louisa Möring, London: Cambridge Mass.

Mintaredja, Abbas Hamami. 2003. Common Sense Epistemological Theories (Teori-teori Epistemologi Common Sense). Yogyakarta: 'Paradigma' Yogyakarta.

Munir, Misnal. 2008. Major Schools of Contemporary Western Philosophy (Aliran-aliran Utama Filsafat Barat Kontemporer) Yogyakarta: LIMA.

Nasution, Harun. 1989. Philosophy of Religion (Filsafat Agama). Jakarta: PT Bulan Bintang.

Praja, Juhaya S. 1993. Schools of Philosophy and Ethics (Aliran-aliran Filsafat dan Etika). Jakarta: Prenada Media.

Russell, Bertrand. 2004. History of Western Philosophy. Translated by Sigit Sujatmiko, et. al., "Sejarah Filsafat Barat". Yogyakarta: Pustaka Pelajar.

Schmadt, Henry J. 2005. Philosophy of Politics (Filsafat Politik). Yogyakarta: Pustaka Pelajar.

Solomon, Robert C. \& Kathleen M. Higgins. 2003. A Short History of Philosophy, translated by Saut Pasaribu, "Sejarah Filsafat". Yogyakarta: Bentang Budaya.

Suriasumantri, Jujun S. 1993. Philosophy of Science: A Popular Introduction (Filsafat Ilmu: Sebuah Pengantar Populer). Jakarta: Pustaka Sinar Harapan.

Tafsir, Ahmad. 2008. General Philosophy: Reason and Heart from Thales to Capra (Filsafat Umum, Akal dan Hati Sejak Thales Sampai Capra). Bandung: Rosda.

Verhaak, Christ. 1993. Francis Bacon: Pioneer of the Philosophy of Science (Francis Bacon: Perintis Filsafat IImu Pengetahuan), in Driyarkara Redaction Team, "The Nature of Knowledge and How the Sciences Work (Hakikat Pengetahuan dan Cara Kerja IImuilmu)". Jakarta: PT Gramedia Pustaka Utama.

Wattimena, Reza A. A. 2010. Philosophy and Science: An Introduction (Filsafat dan Sains: Sebuah Pengantar). Jakarta: Grasindo.

Yuana, Kumara Ari. 2010. The Greatest Philosophers. Yogyakarta: Andi. 